\title{
Long-Term Successional Trends Following Western Juniper Cutting
}

\author{
Jon D. Bates, ${ }^{1}$ Richard F. Miller, ${ }^{2}$ and Tony Svejcar ${ }^{3}$ \\ Authors are ${ }^{1}$ Rangeland Scientist, United States Department of Agriculture, Agricultural Research Service; ${ }^{2}$ Professor, \\ Rangeland Resources Department, Oregon State University; ${ }^{3}$ Research Leader and Range Scientist, USDA-ARS, Burns. \\ Authors are located at the Eastern Oregon Agricultural Research Center, 67826-A Hwy. 205, Burns, OR, 97720.
}

\begin{abstract}
Western juniper (Juniperus occidentalis spp. occidentalis Hook.) expansion into sagebrush steppe plant communities in the northern Great Basin has diminished shrub-steppe productivity and diversity. Chainsaw cutting of western juniper woodlands is a commonly applied practice for removing tree interference and restoring understory composition. Studies reporting understory response following juniper cutting have been limited to early successional stages. This study assessed successional dynamics spanning 13 years following tree cutting. Total herbaceous standing crop and cover increased significantly in the CUT. Total standing crop was 10 times greater in the CUT vs. WOODLAND. Herbaceous standing crop and cover, and densities of perennial grasses in the CUT did not change between 1996 and 2004 indicating that by the 5th year after cutting, remaining open areas had been occupied. In the early successional stages, perennial bunchgrasses and Sandberg's bluegrass were dominant. By the 5th year after treatment, cheatgrass had supplanted Sandberg's bluegrass and was codominant with perennial bunchgrasses. In 2003 and 2004, perennial bunchgrasses dominated herbaceous productivity in the CUT, representing nearly $90 \%$ of total herbaceous standing crop. A pretreatment density of 2-3 perennial bunchgrasses $\mathrm{m}^{-2}$ appeared to be sufficient to permit natural recovery after juniper control. Perennial bunchgrass density peaked in the 6th year after treatment and the results suggested that 10-12 plants $\mathrm{m}^{-2}$ were sufficient to fully occupy the site and dominate herbaceous composition in subsequent years. In the CUT, juniper rapidly reestablished from seed and from the presence of seedlings not controlled in the initial treatment. The shifts in herbaceous composition across years suggests that long term monitoring is important for evaluating plant community response to juniper control and to develop appropriate post treatment management to promote continued site improvement.
\end{abstract}

\section{Resumen}

La expansión del "Western juniper" (Juniperus occidentalis spp. occidentalis Hook.) en las comunidades vegetales de las estepas de "Sagebrush" de la Gran Cuenca del norte ha disminuido la productividad de esta estepa arbustiva y su diversidad. La tala de bosques de "Western juniper" con sierra de cadena es una práctica comúnmente usada para remover la interferencia de los árboles y restaurar la composision del estrato vegetal inferior. Los estudios que reportan la respuesta del estrato vegetal inferior posterior al corte del "Western juniper" han sido limitados a los primeros estados sucesionales. Este estudio aborda las dinámicas sucesionales medidas durante un periodo de 13 años después del corte de los árboles. La biomasa total y cobertura de herbáceas se incrementaron significativamente con el corte de los árboles. La biomasa total fue 10 veces mayor en las áreas con corte de arboles (CUT) que en las áreas intactas (WOODLAND). En el tratamiento con corte (CUT), la biomasa, cobertura y densidades de zacates perennes no cambiaron durante 1996 y 2004, indicando que para el quinto año después del corte las areas abiertas remanentes habían sido ocupadas. En las etaps tempranas de la sucesion, los zacates perennes amacollados y el "Sandberg's bluegrass" (Poa sandbergii Vasey) fueron los dominantes. En quinto año después de aplicar el tratamiento, el "Cheatgrass" había suplantado al "Sandberg's bluegrass" y fue la especie codominante con los zacates amacollados perennes. En 2003 y 2004, los zacates amacollados pernnes dominaron la productividad del estrato herbáceo en el tratamiento de corte (CUT), representando casi el $90 \%$ del total de la biomasa herbácea. Antes de aplicar el tratamiento, una densidad de zacates amacollados de 2 a 3 plantas $\mathrm{m}^{-2}$ parecieron ser suficientes para permitir la recuperación natural después del control del "Western juniper." El pico de la densidad de zacates amacollados fue en el sexto año después de aplicar el tratamiento de corte (CUT) y los resultados sugieren que 10-12 plantas $\mathrm{m}^{-2}$ fueron suficientes para ocupar totalmente el sitio y dominar la composición herbácea en los años subsecuentes. En el tratamiento de corte (CUT), el "Western juniper" se reestablecio rapidamente a partir de semilla y de la presencia de plántulas no controladas en el tratamiento inicial. Las cambios en la composición herbácea a través de los años sugieren que un monitoreo a largo plazo es importante para evaluar la repuesta de la comunidad vegetal al control del "Western juniper" y desarrollar un manejo apropiado post tratamiento para promover la mejoría continua del sitio.

Key Words: Bromus tectorum, cheatgrass, Juniperus occidentalis, shrub-steppe, plant cover, threshold, sagebrush, standing crop

The Eastern Oregon Agricultural Research Center, including the Burns and Union Stations, is jointly funded by the Oregon Agricultural Experiment Station and USDA-Agricultural Research Service.

Correspondence: Jon D. Bates, United States Department of Agriculture, Agricultural Research Service, Eastern Oregon Agricultural Research Center, 67826-A Hwy. 205, Burns, OR, 97720. Email: jon.bates@oregonstate.edu

Manuscript received 26 September 2004; manuscript accepted 21 May 2005. 


\section{INTRODUCTION}

The expansion and development of western juniper (Juniperus occidentalis ssp. occidentalis Hook.) woodlands is of major ecological importance in the northern Great Basin (Miller et al. 2000; Miller and Tausch 2001). Woodlands have increased nine-fold during the past 130 years and encompass an estimated 3.2 million ha across eastern Oregon, southwestern Idaho, and along the northern border of California and Nevada (Miller et al. 2000). Woodland dominance reduces productivity and diversity of shrub-steppe communities (Bates et al. 2000; Miller et al. 2000), results in decreased avian diversity (Miller et al. 1999), and might negatively impact hydrologic processes (Buckhouse and Mattison 1980; Miller at al. 2005). To address these consequences, western juniper has been controlled by a variety of methods, including prescribed fire and mechanical removal by cutting with chainsaws or tractor mounted shears. A main goal of western juniper treatments is to restore northern Great Basin shrub-steppe plant communities.

Cutting treatments are mainly applied to woodlands with depleted shrub and herbaceous understories (Miller et al. 2000). These woodlands have crossed an ecological threshold where fire, either natural or prescribed, is no longer a management option for recovery of the prewoodland plant community. Cutting of western juniper increases availability of soil water and nitrogen, and results in large increases in biomass and cover of herbaceous species within the first two years after treatment (Bates et al. 2000, 2002). Removal of western juniper has been rated either successful (Rose and Eddleman 1994; Bates et al. 2000; Eddleman 2002) or unsuccessful (Evans and Young 1985; Vaitkus and Eddleman 1987) at rehabilitating plant communities with desired herbaceous vegetation. For example, in studies where herbaceous recovery was rated successful, cover and productivity of perennial grasses and forbs exceeded the response of exotic annual grasses (Rose and Eddleman 1994; Bates et al. 2000). The conclusions derived from these studies have been largely based on short-term plant response, occurring within the first two years following juniper treatment. However, sites that are cut are often characterized by large areas of bare ground (Miller et al. 2000), which remain open to plant colonization beyond the initial two years following removal of juniper (Bates et al. 1998, 2000). Young et al. (1985) measured plant productivity for six years after control of western juniper with picloram pellets. Their results indicated that three to five years were required for seeded perennial grasses to fully respond to juniper removal. The lack of long-term vegetation measurements after juniper cutting makes it difficult to properly evaluate herbaceous recovery and compositional changes. Belsky (1996) concluded that the lack of extensive data sets did not justify western juniper control and could result in inappropriate woodland management.

The purpose of this study was to evaluate long-term vegetation succession after the cutting of western juniper, by revisiting a site where short term (two years post treatment) plant succession after juniper cutting was previously reported (Bates et al. 1998, 2000). Early successional data indicated that the cutting of trees was effective at increasing total understory biomass, cover, and diversity within the first two years after cutting (Bates et al. 2000). Plant composition during early succession, largely dictated by pretreatment site floristics, was dominated by native perennial grasses and forbs. From these efforts, it was hypothesized that the annual stage of succession had been bypassed after cutting and that further plant colonization of remaining open spaces would mainly be composed of native perennials. One objective of the study was to determine if these initial predictions, based on two years of early successional plant recovery, would be supported by longer-term results. Additional objectives were to compare vegetation dynamics between the cut treatment and uncut woodlands to ascertain the extent of shrub and herbaceous recovery after cutting, and to quantify reestablishment of juniper back into the cutting treatment.

\section{MATERIALS AND METHODS}

This study spanned a 13-year interval from 1991 through 2004. Data from 1991 through 1993 addressed the effects of the cutting disturbance on initial plant successional dynamics (Bates et al. 1998, 2000). This manuscript mainly compares vegetation data, collected in 1993 (2nd year post cutting), with data collected from 1994 to1997 and 2003 to 2004 to assess long-term effects of the juniper cutting on vegetation successional dynamics. Pretreatment and 1st year vegetation response to cutting (cover and density), extensively reported in Bates et al. (2000), are only briefly presented in this paper. Plots were visually monitored to detect major compositional shifts but were not sampled between 1998 and 2002.

\section{Site Description and Experimental Design}

The study site was located on Steens Mountain, southeastern Oregon $\left(118^{\circ} 36^{\prime} \mathrm{E}, 42^{\circ} 55^{\prime} \mathrm{N}\right)$. Elevation at the site is 1550 $\mathrm{m}$ and aspect is facing west with a $22 \%$ slope. Precipitation occurs mostly in winter and early spring. Summers are warm and dry. Annual precipitation (1 October to 20 September) at the Malheur National Wildlife Refuge weather station $(1250 \mathrm{~m})$, located 29 kilometers northwest of the site, has averaged $248 \mathrm{~mm}$ over the past 44 years (Fig. 1). Prior to cutting, juniper canopy cover averaged $26 \%$ and mature tree density averaged 250 trees ha ${ }^{-1}$ (Bates et al. 2000). The interspace zone was $95 \%$ bare ground and Sandberg's bluegrass (Poa sandbergii Vasey) was the dominant understory species (Bates et al. 2000).

Four 0.9-ha blocks were established in June $1991^{1}$. Each block was divided into two 0.45 -ha-sized plots. One plot within each block was randomly assigned the cutting treatment (CUT) and the remaining plot was left as woodland (WOODLAND). In the CUT treatment, all mature trees and saplings $>20 \mathrm{~cm}$ in height were felled using chainsaws in August 1991. Felled trees were left in place (Bates 1996). Livestock were excluded during the study.

\footnotetext{
${ }^{1}$ In our earlier study (Bates et al. 2000) there were eight 0.9 ha blocks. After 1993, four blocks were put back into pasture and are being used in an observational grazing study. The four blocks used in this study were fenced off and have not been grazed.
} 


\section{Vegetation Measurements}

Understory measurements included estimates of canopy cover, density, and standing crop at the functional group level. Functional groups were composed of Sandberg's bluegrass, deep rooted perennial bunchgrasses (e.g., Thurber's needlegrass [Stipa thurberiana Piper] and bluebunch wheatgrass [Agropyron spicatum Pursh Scribn. \& Smith]), bottlebrush squirreltail (Sitanion hystrix [Nutt.] Smith), cheatgrass (Bromus tectorum L.), perennial forbs, and annual forbs. The criterion for determining functional groups was described in Bates et al. (2000).

Density and canopy cover of herbaceous species were measured inside $0.2-\mathrm{m}^{2}$ frames. Canopy cover and plant density were estimated spatially by zone in 1991-1993, 1997, and 2003-2004. CUT areas were spatially stratified into interspace, canopy (litter area formerly beneath standing trees), and debris (under cut trees) zones. In the WOODLAND, zones were stratified into interspace and canopy (within tree canopy dripline). Canopy and interspace zones were measured in the four cardinal directions around 12 randomly selected tree stumps each year in each plot. For the canopy zone, frames were placed on the outer edge of the litter/dripline area. Interspace zones were sampled about $3 \mathrm{~m}$ from the outer edge of the canopy. For the debris zone, frames were randomly placed under 12 cut juniper trees (four frames per tree). Plant densities 1994-1996 and 2004 and canopy cover in 1994 and 2004 were not stratified by zone, but were whole plot estimates. In these sample years, frames were placed every $2 \mathrm{~m}$ along five, $30.5 \mathrm{~m}$ transect lines.

Shrub and tree canopy cover were measured by line intercept along five, $30.5 \mathrm{~m}$ transect lines. Densities of shrubs, and juniper seedlings and saplings $(<1 \mathrm{~m}$ height) were estimated using $2 \mathrm{~m} \times 30.5 \mathrm{~m}$ belt transects. Juniper $(>1 \mathrm{~m}$ height) density was estimated using $6 \mathrm{~m} \times 30.5 \mathrm{~m}$ belt transects. Zonal areas (canopy, interspace, and debris) were also determined by line intercept along each transect.

In June 1992 and 1993, herbaceous standing crop was sampled by functional group using $251-\mathrm{m}^{2}$ frames per plot. In June 1997 and 2003, functional group standing crop was sampled by zone in each plot replicate using $25,1-\mathrm{m}^{2}$ frames. In 1996, total standing crop was not segregated by functional group or zone. Herbage was clipped to a $2-\mathrm{cm}$ stubble height and dried at $48^{\circ} \mathrm{C}$ for $48 \mathrm{~h}$ prior to weighing.

\section{Statistical Analysis and Data Organization}

To simplify presentation of the results, we focused on treatment responses over time and did not compare zonal values. This was also done because sampling was not spatially stratified among zones in all years. To compare treatments across years, a main objective of the study, weighted zonal means were used to obtain overall plot means. Zonal means for standing crop, cover, and density were weighted by the area occupied by each zone (years 1991-1993, 1997, and 2003) to obtain whole plot means for the treatments. The area of each zone was determined by line intercept from transects established in each plot. Because zones were not spatially stratified while sampling from 19941996 and 2004, these values did not require adjustment.

Analysis of variance was used to test for treatment effect on herbaceous standing crop (functional group and total herbaceous), cover (species and functional group), and density

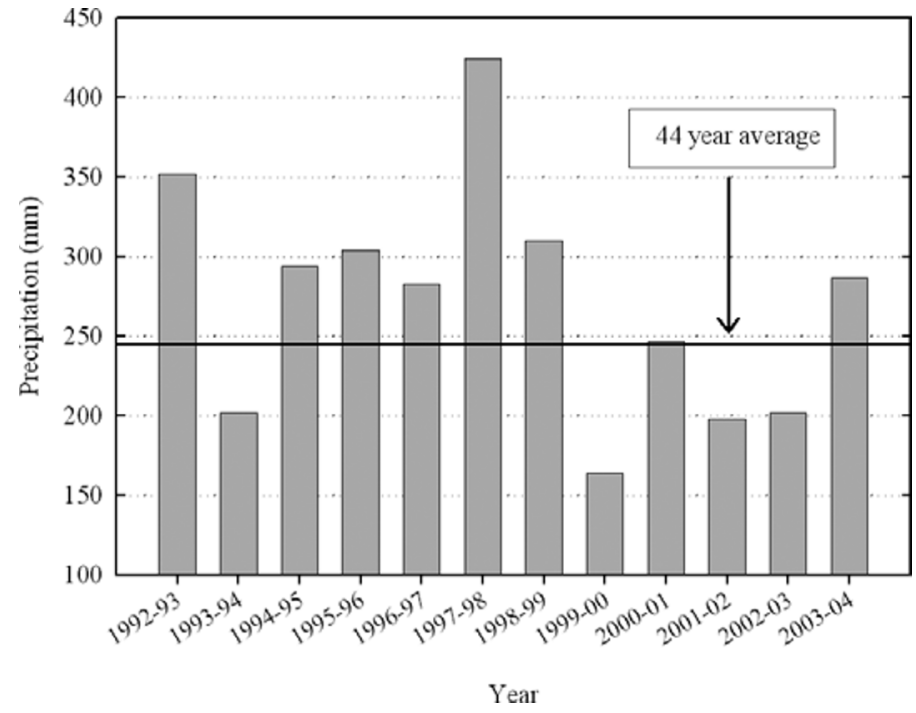

Figure 1. Annual precipitation (mm) for years 1993-2003 and the longterm average at the Malheur National Wildlife Refuge weather station (1 $250 \mathrm{~m})$, located 29 kilometers northwest of the site.

(species and functional group). Cover and density of shrubs and juniper were analyzed by species. Response variables were analyzed as a randomized complete block across time. The model included block (four blocks, df = 3), year (1991-1997 and 2003, $\mathrm{df}=7$ ), treatment (CUT, WOODLAND, $\mathrm{df}=1$ ), and year by treatment interaction $(\mathrm{df}=7$; with the error term $\mathrm{df}=45$ ). All statistical analyses were performed using the Statistical Analysis System (SAS Institute 2002). Data were tested for normality using the SAS univariate procedure. Data not normally distributed were arcsine square root transformed to stabilize variance. Back transformed means are reported. Statistical significance of all tests was set at $P<0.05$ and mean separations were accomplished using Fisher's protected LSD.

\section{RESULTS AND DISCUSSION}

\section{Treatment Comparisons; Herbaceous Standing Crop}

During the five sampling years, herbaceous standing crop was always greater in the CUT compared to the WOODLAND (Fig. 2). Main effects (time, treatment) and the interaction (year and treatment) were highly significant for total and functional group standing crop. Total standing crop in the CUT was significantly greater than the WOODLAND in all measurement years. The interaction indicated that herbaceous standing crop increased significantly in the CUT treatment between 1992 (1st year post cutting) and 1996 (5th year post cutting). Since 1996, standing crop in the CUT has remained at about $1000 \mathrm{~kg} \cdot \mathrm{ha}^{-1}$ and has been nine to 12 times greater in the CUT compared to the WOODLAND. This level of herbaceous biomass response in the CUT is not unusual following juniper treatment. In other western juniper and pinyon-juniper woodlands of the Great Basin, 2- to 10-fold increases in herbaceous biomass have been documented after juniper control (Young et al. 1985; Clary 1987; Vaitkus and Eddleman 1987; Rose and Eddleman 1994; Bates et al. 2000). Bates et al. (2000) established that increased 


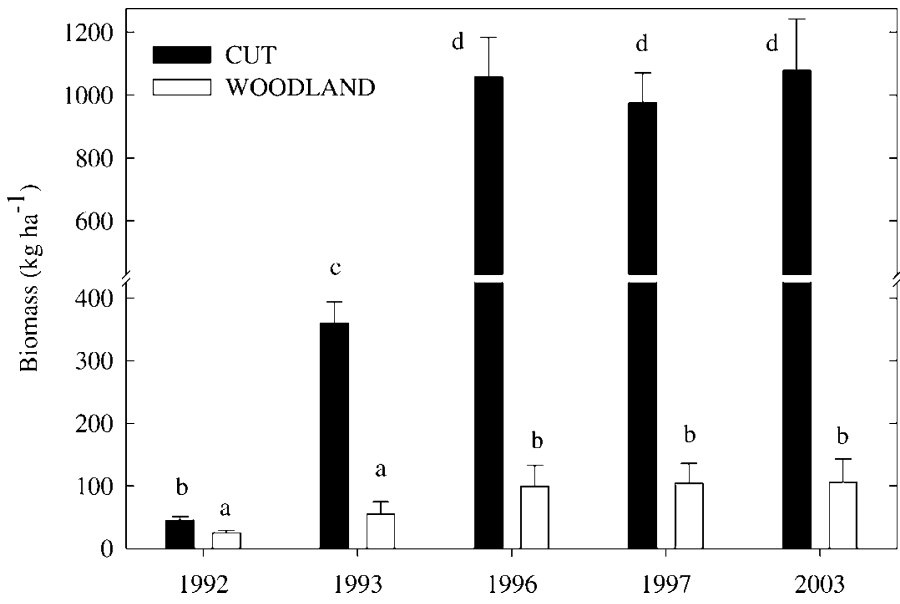

Figure 2. Total biomass $\left(\mathrm{kg} \cdot \mathrm{ha}^{-1}\right)$ in CUT and WOODLAND treatments. Values are means \pm one standard error. Different lower case letters indicate significant differences $(P>0.05)$ between the treatments within year.

understory productivity after juniper cutting resulted from greater availability of soil water and nitrogen. In the present study, soil water and available nitrogen were not measured, but the greater understory productivity and higher cover in the CUT indicates that water and soil nutrients remain more available for herbaceous plant uptake than in the WOODLAND.

Standing crop of the functional groups tended to be greater in the CUT than the WOODLAND, although for several of the response variables, this relationship was not consistent across all years (Figs. 3A-3D). Perennial grass standing crop was greater in the CUT than the WOODLAND in all measurement years. The relative difference between treatments for perennial grass standing crop increased with time $(P<0.01)$. By 2004, perennial grass standing crop in the CUT was 16 times greater than in the WOODLAND (Fig. 3D). Cheatgrass standing crop was greater in the CUT than in the WOODLAND, particularly in 1997, the sixth year after treatment (Fig. 3B). However, cheatgrass biomass has declined significantly in the CUT since 1997. By 2004, cheatgrass represented only $4 \%$ of total standing crop in the CUT (Fig. 3D). In the CUT, there were initial increases in Sandberg's bluegrass and perennial forb production, but both have declined in productivity in recent years. In 1997, 2003, and 2004, Sandberg's bluegrass production did not differ between CUT and WOODLAND treatments. Standing crop of perennial forbs has not differed between treatments the past two measurement years. Annual forb standing crop was greater in the CUT compared to the WOODLAND, but represented only a small portion $(<5 \%)$ of total standing crop in the CUT.

\section{Treatment Comparisons; Herbaceous Cover and Density}

Treatment differences and trends in herbaceous plant cover and perennial plant densities paralleled results reported for standing crop. In the CUT, herbaceous cover and density increased over time as areas open to plant establishment were occupied. Total herbaceous cover (Table 1) and perennial grass cover (Fig. 4A) were significantly greater in the CUT compared to the WOODLAND in all years following treatment (Table 1). Cheatgrass cover has tended to be greater in the CUT than

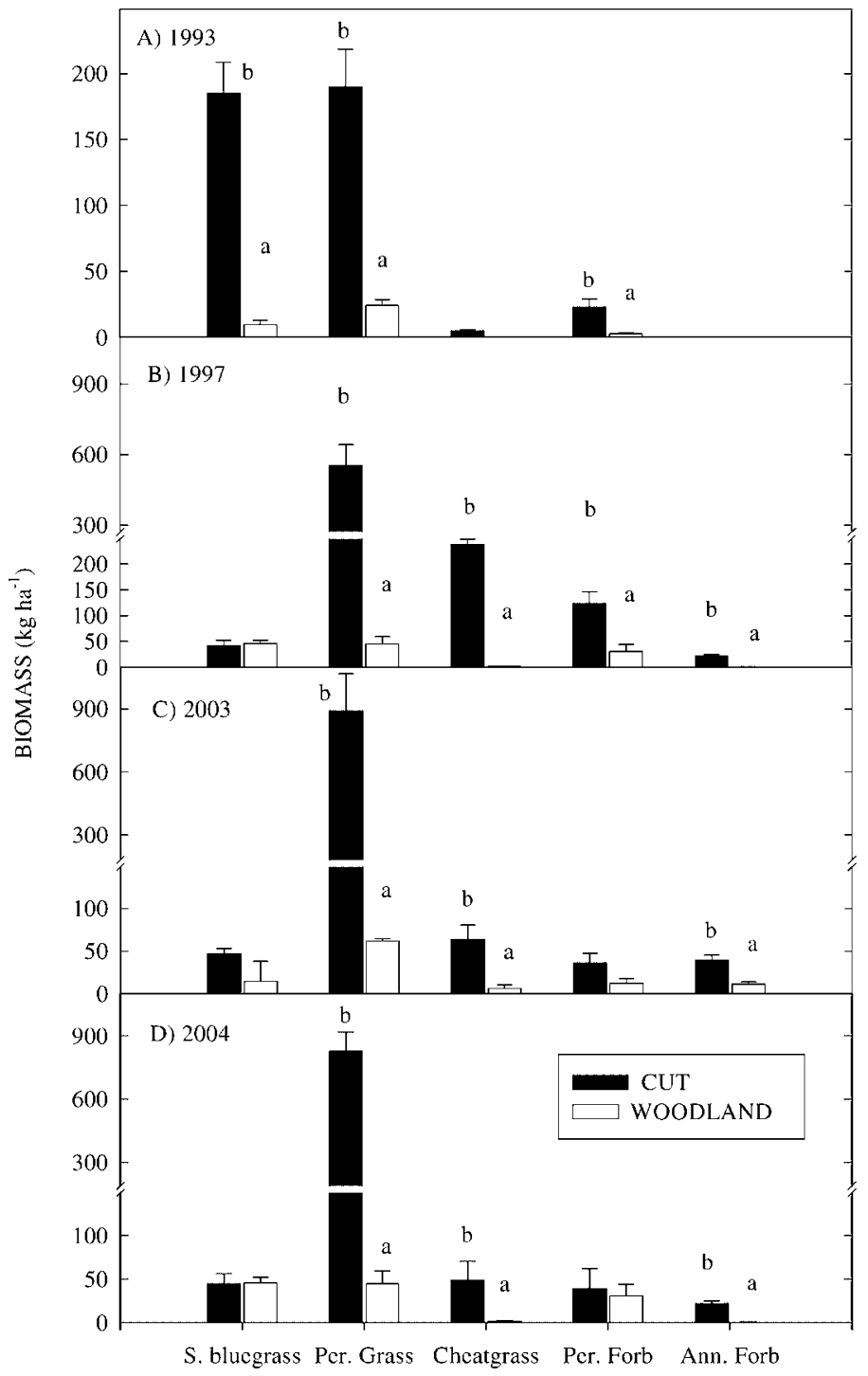

Figure 3. Biomass $\left(\mathrm{kg} \cdot \mathrm{ha}^{-1}\right)$ by functional groups in (A) 1993, (B) 1997, (C) 2003 and (D) 2004. Data are in means \pm one standard error. Significant differences $(P>0.05)$ between the CUT and WOODLAND treatments by year and by functional group are indicated by different lower case letters. Functional groups are Sandberg's bluegrass (S. bluegrass); Perennial Grass (Per. Grass); Cheatgrass; Perennial Forb (Per. Forb); and Annual Forb (Ann. Forb).

the WOODLAND since the 3rd growing season (1994) after treatment (Fig. 4B). However, as cheatgrass cover has declined in the CUT, differences between treatments became less apparent. Cover of Sandberg's bluegrass, perennial forbs, and annual forbs was greater in the CUT in the years immediately following treatment but has not differed from the WOODLAND the past two growing seasons (Figs. 4C-4E).

Perennial grass density (Fig. 5A) was greater in the CUT than the WOODLAND by the 2 nd growing season (1993) following treatment. Treatment differences for perennial grass density increased over the next four growing seasons (1994-1997). Although 1994 was a very dry year, the 1993-97 period generally had above average precipitation (Fig. 1), which probably favored perennial bunchgrass establishment. In 1997, 2003, and 
Table 1. Comparisons of cover (\%) and tree and shrub density values collected on Steens Mountain, Oregon, as affected by juniper cutting treatment. Values are means \pm one standard error.

\begin{tabular}{|c|c|c|c|c|c|c|c|}
\hline Year \& & $\begin{array}{c}\text { Herbaceous } \\
\text { Cover }\end{array}$ & $\begin{array}{l}\text { Bare ground } \\
\& \text { Rock }\end{array}$ & Litter $^{1}$ & $\begin{array}{l}\text { Tree } \\
\text { Cover }\end{array}$ & $\begin{array}{l}\text { Shrub } \\
\text { Cover }\end{array}$ & $\begin{array}{c}\text { Tree } \\
\text { Density }^{2}\end{array}$ & $\begin{array}{l}\text { Shrub } \\
\text { Density }\end{array}$ \\
\hline Treatment & $\%$ & $\%$ & $\%$ & $\%$ & $\%$ & $\#$ ha $^{-1}$ & $\#$ ha $^{-1}$ \\
\hline \multicolumn{8}{|l|}{$1991^{3}$} \\
\hline CUT & $5.4 \pm 0.6 \mathrm{a}$ & $68.9 \pm 3.8 d$ & $25.8 \pm 1.9 \mathrm{a}$ & $24.4 \pm 4.4 \mathrm{~b}$ & $0.0 \pm 0.0$ & $316.2 \pm 24.7 c$ & $15.2 \pm 12.3 \mathrm{a}$ \\
\hline WOODLAND & $4.2 \pm 0.8 \mathrm{a}$ & $65.8 \pm 2.1 d$ & $30.1 \pm 1.3 b$ & $27.3 \pm 1.0 b$ & $0.0 \pm 0.0$ & $325.5 \pm 20.7 \mathrm{c}$ & $13.2 \pm 10.8 \mathrm{a}$ \\
\hline \multicolumn{8}{|l|}{1992} \\
\hline CUT & $10.7 \pm 2.4 b$ & $57.9 \pm 2.8 c$ & $31.4 \pm 2.4 b$ & $0.0 \pm 0.0 \mathrm{a}$ & $0.0 \pm 0.0$ & $79.3 \pm 23.5 \mathrm{a}$ & $13.4 \pm 12.1 \mathrm{a}$ \\
\hline WOODLAND & $5.2 \pm 0.5 \mathrm{a}$ & $67.3 \pm 2.8 d$ & $27.5 \pm 1.7 \mathrm{a}$ & $25.6 \pm 1.8 b$ & $0.0 \pm 0.0$ & $328.3 \pm 21.3 c$ & $12.6 \pm 9.4 \mathrm{a}$ \\
\hline \multicolumn{8}{|l|}{1993} \\
\hline CUT & $22.7 \pm 0.8 \mathrm{c}$ & $45.3 \pm 1.3 b$ & $32.0 \pm 0.9 \mathrm{~b}$ & $0.0 \pm 0.0 \mathrm{a}$ & $0.0 \pm 0.0$ & $85.4 \pm 30.5 a$ & $24.4 \pm 22.1 \mathrm{a}$ \\
\hline WOODLAND & $6.0 \pm 0.7 \mathrm{a}$ & $64.2 \pm 1.7 \mathrm{~cd}$ & $29.9 \pm 1.0 a b$ & $27.6 \pm 1.6 b$ & $0.0 \pm 0.0$ & $318.5 \pm 27.3 c$ & $11.2 \pm 8.9 \mathrm{a}$ \\
\hline \multicolumn{8}{|l|}{1994} \\
\hline CUT & $28.1 \pm 1.3 \mathrm{~d}$ & $41.2 \pm 2.5 b$ & $33.2 \pm 1.9 b$ & N.M. ${ }^{4}$ & N.M. & N.M. & N.M. \\
\hline WOODLAND & $5.8 \pm 0.9 \mathrm{a}$ & $61.8 \pm 2.2 \mathrm{c}$ & $32.3 \pm 3.0 b$ & & & & \\
\hline \multicolumn{8}{|l|}{1997} \\
\hline CUT & $35.9 \pm 2.8 \mathrm{e}$ & $35.3 \pm 2.2 \mathrm{a}$ & $33.1 \pm 1.9 b$ & $0.2 \pm 0.2 \mathrm{a}$ & $1.4 \pm 1.0$ & $129.7 \pm 29.3 \mathrm{a}$ & $887.5 \pm 686.4 b$ \\
\hline WOODLAND & $6.6 \pm 1.4 \mathrm{a}$ & $60.6 \pm 1.7 \mathrm{c}$ & $32.7 \pm 1.4 b$ & $24.7 \pm 2.0 \mathrm{~b}$ & $0.0 \pm 0.0$ & $335.4 \pm 39.1 \mathrm{c}$ & $14.8 \pm 14.8 \mathrm{a}$ \\
\hline \multicolumn{8}{|l|}{2003} \\
\hline CUT & $26.8 \pm 2.8 \mathrm{~cd}$ & $41.0 \pm 2.4 b$ & $32.0 \pm 2.5 b$ & $0.7 \pm 0.3 \mathrm{a}$ & $2.5 \pm 1.2$ & $222.2 \pm 32.7 \mathrm{~b}$ & $630.0 \pm 309.0 \mathrm{~b}$ \\
\hline WOODLAND & $5.7 \pm 0.9 a$ & $69.3 \pm 3.2 d$ & $27.1 \pm 2.6 a b$ & $24.7 \pm 2.0 \mathrm{~b}$ & $0.0 \pm 0.0$ & $312.0 \pm 14.8 \mathrm{c}$ & $14.8 \pm 14.8 \mathrm{a}$ \\
\hline \multicolumn{8}{|l|}{2004} \\
\hline CUT & $25.1 \pm 1.5 \mathrm{~cd}$ & $40.8 \pm 2.4 b$ & $34.5 \pm 4.0 \mathrm{~b}$ & $0.8 \pm 0.3 a$ & $1.2 \pm 0.9$ & $268.2 \pm 45.0 \mathrm{bc}$ & $489.5 \pm 159.7 b$ \\
\hline WOODLAND & $4.5 \pm 0.5 \mathrm{a}$ & $56.2 \pm 6.5 c$ & $31.6 \pm 2.5 b$ & $29.6 \pm 4.0 \mathrm{~b}$ & $0.0 \pm 0.0$ & $370.3 \pm 44.3 \mathrm{c}$ & $8.3 \pm 3.6 \mathrm{a}$ \\
\hline
\end{tabular}

Different lower case letters indicates significant differences between treatment means within a column $(P<0.05)$.

${ }^{1}$ Litter in cut plots includes litter in intercanopy, debris, and canopy zones. Litter in woodlands is primarily under trees with less than $2 \%$ litter in the interspace.

${ }^{2}$ Tree density includes all trees from seedling to large mature trees. Mature tree density averaged 250 trees ha $^{-1}$.

${ }^{3}$ Pretreatment data is presented for readers to compare treatment dynamics over the 13-year study period.

${ }^{4}$ N.M. - not measured.

2004, perennial grass density was about 5 times greater in the CUT compared to the WOODLAND. Densities of Sandberg's bluegrass and perennial forbs were not different between treatments, and mean values, while fluctuating, did not change during the study period (Figs. 5B-5C).

The shift in plant cover from juniper dominance in the WOODLAND to herbaceous dominance in the CUT (Table 1) has important hydrologic implications. If total plant cover (tree, shrub, and herbaceous) is compared, there is no difference between the CUT and the WOODLAND after 1997 (e.g., in 2003 total plant cover was $30.0 \pm 1.9 \%$ in the CUT and $30.4+1.5 \%$ in the WOODLAND). However, the distribution of plant cover, as well as litter, was different between the treatments. Plant cover and litter are more evenly distributed in the CUT, which was reflected by the lower percentage of bare ground recorded (Table 1). In contrast, plant cover and litter are less evenly distributed in the WOODLAND, resulting in a higher percentage of bare ground. By increasing the density of plant cover and litter, soil surfaces are better protected from raindrop impact and the higher cover slows or prevents water movement across the soil surface, thus reducing erosion potential (Blackburn et al. 1994; Davenport et al. 1998). On our study site, the increase in herbaceous cover and reduction in bare ground in the CUT resulted in significantly reduced runoff and sheet erosion (measured from in situ rainfall simulation plots) compared to the WOODLAND (Miller et al. 2005).

\section{Herbaceous Succession after Cutting}

In the CUT, total standing crop (Fig. 2) and cover (Table 1) has not changed significantly since the 5 th year after treatment, indicating that it took about five years for understory herbaceous species to colonize and occupy remaining open areas. Results from other studies have shown that approximately five years were required for herbaceous standing crop to peak after western juniper treatment (Young et al. 1985) and two to four years for herbaceous cover to peak following chaining of pinyonjuniper woodlands in Nevada (Tausch and Tueller 1977).

However, compositional changes and establishment of new plants demonstrated that plant succession in the CUT remained a dynamic process. In the early successional stages (19921994), perennial grass and Sandberg's bluegrass were dominant (Fig. 3A). Between 1995 and 1997, perennial grasses and cheatgrass were dominant. Herbaceous vegetation was not measured between 1998 and 2002, but our observations indicated that perennial grasses and cheatgrass continued to dominate the 


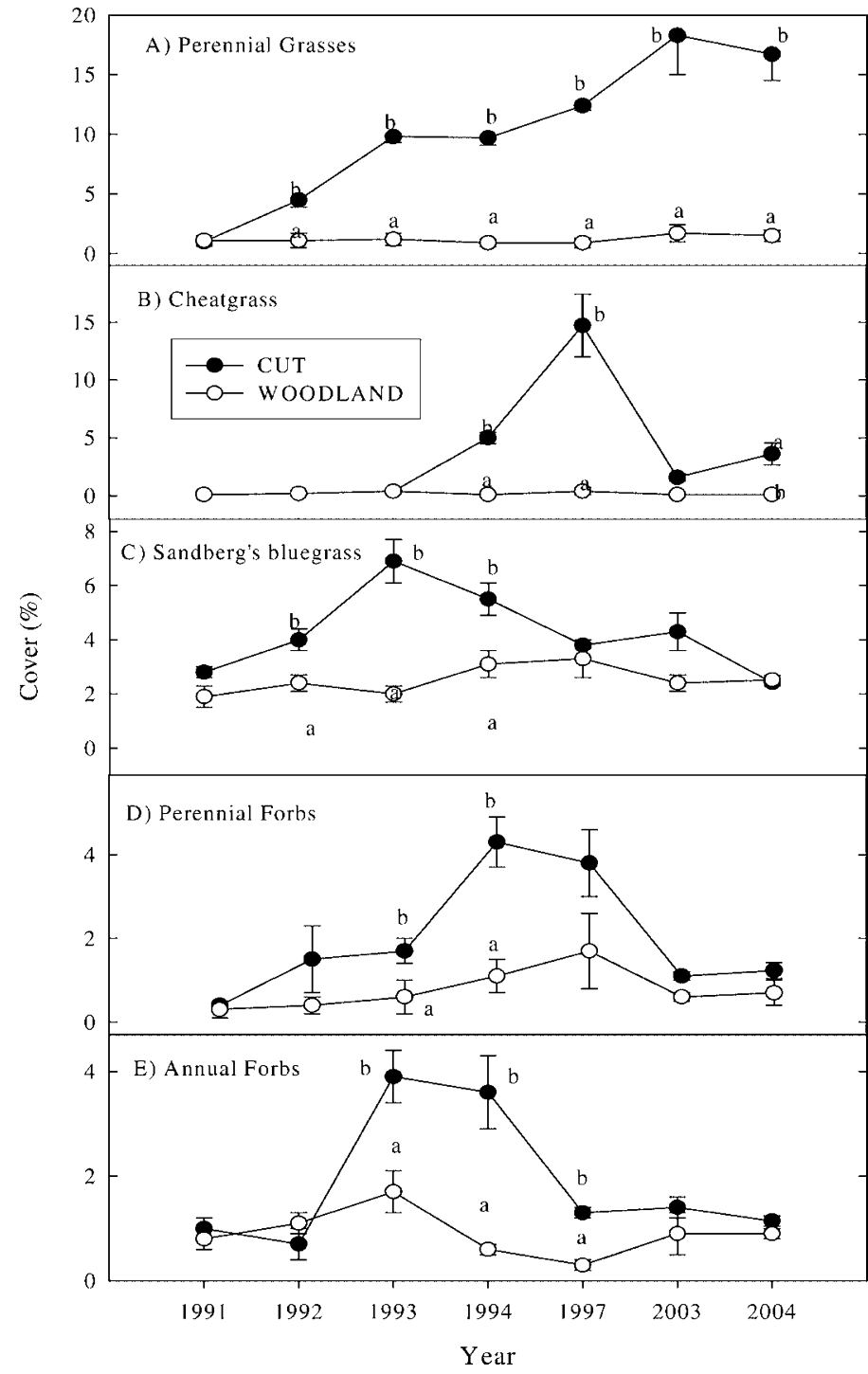

Figure 4. Functional group cover (\%) in the treatments in 1991-1994, 1997, 2003, and 2004 for: (A) Perennial Grasses; (B) Cheatgrass; (C) Sandberg's bluegrass; (D) Perennial Forbs; and (E) Annual Forbs. Data are in means \pm one standard error. Significant differences $(P>0.05)$ between treatments for each response variable are indicated by different lower case letters.

CUT treatment. By 2003, cheatgrass standing crop (Fig. 3C), and cover (Fig. 4B) had decreased significantly from 1997. In 2003 and 2004, the 12th and 13th year after treatment, perennial grasses dominated the herbaceous layer in terms of standing crop (Figs. 3C and 3D) and cover (Fig. 4A). Perennial grass standing crop represented nearly $90 \%$ of total herbaceous standing crop in those years. These results support our hypothesis that as open spaces were colonized, perennial grasses would become increasingly dominant in the CUT. Eddleman (2002) reported that perennial grasses became dominant in later successional stages following control of western juniper. As was prescribed in our study, Eddleman's (2002) research also depended on natural recovery. Natural recovery is defined here as secondary succession developing from plant species existing on site prior to treatment.

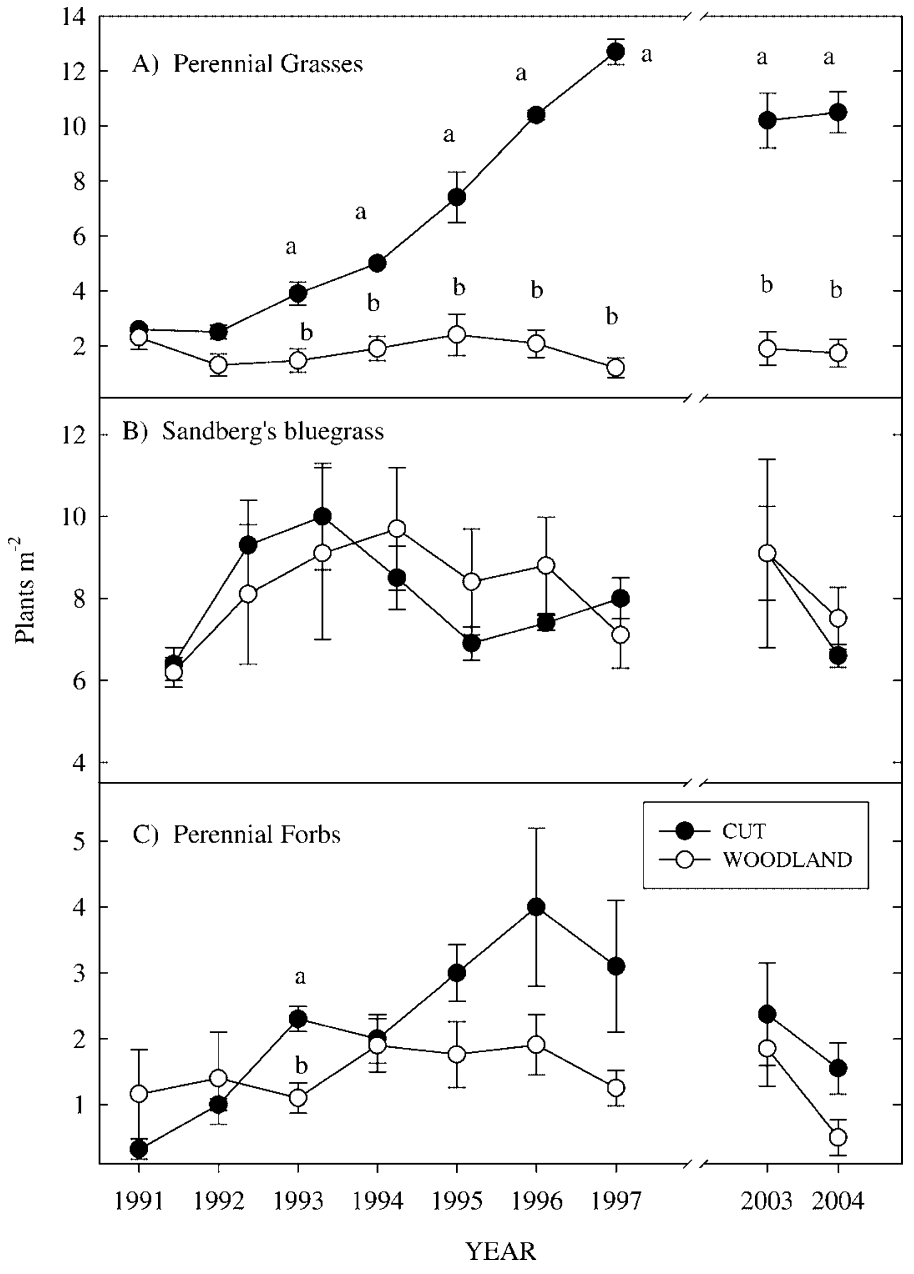

Figure 5. Densities (plants $\mathrm{m}^{-2}$ ) of: (A) Perennial Grasses; (B) Sandberg's bluegrass; and C) Perennial Forbs. Values are in means \pm one standard error. Significant differences $(P>0.05)$ between treatments for each response variable are indicated by different lower case letters. Perennial grass densities increased significantly in the CUT between 1991 and $1997(P>0.001)$.

However, in two other long-term studies the response of exotic annual grasses has exceeded the response of remaining native vegetation (Evans and Young 1985; Young et al. 1985). These sites were characterized by severely depleted native perennial understories prior to treatment, and required the seeding of non-native perennial grasses to prevent annual grass dominance after juniper treatment (Young et al. 1985). The results from these studies and ours imply that pretreatment plant composition can be used as an indicator of understory successional trajectory following juniper control.

These results also suggest that there are recovery thresholds, based on pretreatment perennial grass composition, that would indicate if natural recovery can be expected or if seeding might be required. In our study and Eddleman's (2002), a recovery threshold could be based on pretreatment perennial grass densities. Both studies were located on sites with similar site potential and species composition, where perennial grass densities ranged between two to three plants per $\mathrm{m}^{-2}$ prior to juniper control. This estimate can be used by land managers as a baseline for prescribing natural recovery following juniper 
control on drier, lower elevation plant communities with bluebunch wheatgrass-Thurber's needlegrass in the understory. At a larger scale, evidence to determine recovery thresholds remains limited and recovery thresholds are likely to vary by plant community, site potential, and weed species present.

\section{Cheatgrass Response}

Cheatgrass presence remains a concern in many western juniper woodlands as this species has shown the ability to increase rapidly and dominate following juniper control (Quinsey 1984; Evans and Young 1985). Davis and Harper (1990) also measured large increases in annuals, primarily cheatgrass, within the first two years after chaining pinyon-juniper woodlands in Utah.

The lack of cheatgrass response the first three growing seasons (1992-1994) after treatment lead us to initially conclude that cheatgrass would not be a significant factor in plant succession on the site. Thus, the increase in cheatgrass the 4th through 6th years (1995-1997) after treatment was not anticipated. The lag response of cheatgrass might have been a result of weather conditions. The increase in cheatgrass tended to coincide with years with higher precipitation (Fig. 1). Years with above average precipitation provide ideal conditions for cheatgrass establishment and growth in eastern Oregon (Ganskopp and Bedell 1979). Cheatgrass established primarily in areas with high amounts of litter, suggesting that these areas produced more favorable microsites for cheatgrass germination and growth (Bates et al. 2004). Environmental factors that could have contributed to this zonal preference were greater availability of soil resources (water and nutrients) and protection from temperature extremes (Bates 1996; Bates et al. 1998). Soil water content was greater under juniper debris than in interspace soils on this site (Bates et al. 1998). Evans and Young (1985) reported that soil nitrogen increased in litter deposition areas several years after juniper treatment, which stimulated annual grass response in these zones.

The subsequent decline of cheatgrass between 1997 and 2003 might have resulted from; 1) drought the past several years (Fig. 1) potentially reducing cheatgrass seed production, seedling establishment, and plant growth; 2) less favorable seedbed conditions as litter was incorporated into the soil and exposure increased; 3) reduced soil nutrient availability; and 4) increased competition from perennials. The continued increase of perennial grass biomass and cover during the drought years suggests that perennial suppression of cheatgrass was a primary factor for cheatgrass decline.

\section{Shrub and Juniper Dynamics after Cutting}

Shrubs, mainly basin big sagebrush (Artemisia tridentata spp. tridentata Beetle \& A. Young), increased in density in the CUT, although establishment has been highly variable (Table 1). Other shrub species established on site were gray rabbitbrush (Chrysothamnus nauseous [Pall.] Britt), Wood's rose (Rosa woodsii Lindl.), golden currant (Ribes aureum Pursh), squaw currant (Ribes cereum Dougl.), and gray horsebrush (Tetradymia canescens DC.). Although not significant, sagebrush densities declined between 1997 and 2004. This might have been due to self thinning, because sagebrush seedlings tended to be concentrated in small patches on the site. Sagebrush cover also increased but remains far below site potential (potential is $20 \%$ ) based on National Resource Conservation Service (NRCS) Ecological Site descriptions (NRCS 2004). The response of shrubs in this study have been slower than in other long-term studies in pinyon-juniper woodlands where shrub cover increased rapidly within ten years following treatment (Tausch and Tueller 1977; Skousen et al. 1989). Shrub response appears to be linked to shrub densities prior to treatment. Compared to these other studies, shrub densities on our site were extremely low prior to cutting.

Juniper has rapidly reestablished in the CUT (Table 1), which indicates that the site is in the early phases of returning to a juniper dominated plant community. Juniper density in 2003 and 2004 was over 200 trees per hectare in the CUT. The majority of trees established from seed but about one-third were the small individuals $(<20 \mathrm{~cm})$ which were not controlled in the initial treatment application in 1991. Based on the characteristics of surrounding juniper stands, we estimate that the CUT treatment will be redominated by juniper within 40-50 years.

At some point in the reinvasion process, understory productivity will again decline. Based on relationships between herbaceous cover and juniper cover developed by Miller et al. (2000), we estimate that the understory will not begin to noticeably decline until juniper cover approaches 5-10\%. Juniper cover was less than $1 \%$ in 2004 (Table 1), 13 years after cutting. In contrast, Tausch and Tueller (1977) reported that understory cover and production declined steadily after the 6th year following chaining of pinyon-juniper woodland, as shrubs and trees re-occupied treated sites. The earlier decline in understory production and cover following chaining, mainly results from less effective tree removal (Tausch and Tueller 1977; Skousen et al. 1989) when compared to cutting (Bates et al. 2000; Eddleman 2002). Percentages of pinyon-juniper trees removed by chaining ranged from $46 \%$ to $91 \%$ in Utah (Skousen et al. 1989). Chaining treatments in Nevada reduced tree density by less than $60 \%$ and tree cover by $84 \%$ (Tausch and Tueller 1977). In our cutting treatment, relative tree density was reduced by $73 \%$, but more importantly tree cover was reduced by $100 \%$ (Table 1 ). These comparisons indicate that the more tree cover (e.g. leaf area) is reduced, the longer understory productivity and cover will be maintained following juniper control. Tree cutting, as was prescribed in our study, demonstrates that the influence of juniper can be delayed for a more extended period than is reported for chaining treatments. However, as pointed out earlier, the cutting treatment still missed $27 \%$ of the trees on site (Table 1 ). Woodlands that are cut will require retreatment to prevent juniper from redominating plant communities.

\section{MANAGEMENT IMPLICATIONS AND CONCLUSIONS}

\section{Shrub Steppe Restoration}

In the WOODLAND, understory cover and productivity did not change during the study. The herbaceous characteristics in the WOODLAND indicate that the plant community has crossed a successional threshold and is in a relatively stable state. The successional model developed for western juniper by Miller et al. (2000) indicates that the plant community was 
representative of a closed woodland system and will remain woodland without substantial management inputs to restore the community back to sagebrush steppe.

The results confirm that removal of western juniper will result in increased herbaceous productivity and cover. The composition and speed of plant community response depends on several integrated factors, including site characteristics, pretreatment floristics, and post treatment management, and weather. Vegetation changes in these semi-arid environments are often subtle, and in this study took several years to be expressed. The CUT was still recovering from the latent effects of juniper suppression in 1993 and it wasn't until the fifth and sixth years after cutting (1996-1997) that herbaceous productivity peaked following the initial treatment. Perennial bunchgrass density peaked in the 6th year after treatment (1997) and the results suggested that $10-12$ plants $\mathrm{m}^{-2}$ were sufficient for this functional group to fully occupy the site and dominate herbaceous composition in subsequent years (Figs. 3 and 5; e.g., 2003 and 2004).

The site has not returned to a shrub steppe community, as the CUT presently has the appearance of a grassland. Shrubs have been slow to respond, and at present, juniper cover is equivalent to shrub cover (Table 1 ). The rapid reestablishment of juniper after cutting might, therefore, preclude a shrubsteppe successional phase. Once juniper tree cover increases to a third of a site's potential, shrubs decline rapidly in density and cover (Miller et al. 2000). Thus, the continued development of sagebrush will require the retreatment of juniper.

\section{Livestock Management Considerations}

Cutting of woodlands was beneficial to forage production on this site. In this study, the number of hectares required per animal unit month (AUM) was reduced from about 19 to two, following juniper cutting. From a livestock production standpoint, management flexibility is often increased as the forage base improves (Bedell 1987). The time period required for the understory to respond to juniper control has implications for post treatment livestock grazing management. Grazing in treated woodlands should be designed to meet short and long-term goals that promote restoration of site structural and functional attributes. Specific grazing prescriptions, however, are difficult to apply broadly because sites differ in response to treatment as a result of pretreatment plant composition, site potential, potential for weed infestation, and climate. A goal of many western juniper control treatments is to increase establishment and productivity of perennial composition to benefit forage production, wildlife habitat, and hydrologic stability (Eddleman 1999). In this study, perennial grasses steadily increased in density, cover, and production the first six years after treatment. The increase in plant density was from the recruitment of new individuals that were derived from seed produced on site (Bates et al. 1999). Although densities peaked in 1997, perennial grass production continued to increase in subsequent years. Thus, perennial grass response was far from rapid. The results from this study suggest that in years immediately following juniper control, grazing should be carefully managed in order to promote recruitment and establishment of perennial grasses. Results have shown that even short duration-early season grazing has the potential to reduce recruitment of perennial grasses by diminishing seed production in years immediately following treatment (Bates, 2005). Resting and/or deferring grazing until after seed dispersal should be considered in order to maximize seed crops and encourage establishment of new plants. In later years, grazing must be properly applied to increase or maintain perennial grass productivity and cover. The continued compositional shifts in vegetation across years suggest that long-term studies are valuable for assessing successional responses to juniper treatment, and for developing appropriate management of treated sites.

\section{ACKNOWLEDGMENTS}

We thank Otley Brothers Inc. for use of their property during the study. Thanks to Kara Paintner and Jeff Rose for statistical help and assistance in the field. Thanks are due to Dave Ganskopp and David Bohnert for their comments and suggestions.

\section{LITERATURE CITED}

BATES, J. D. 1996. Understory vegetation response and nitrogen cycling following cutting of western juniper [dissertation]. Corvallis: Oregon State University. $230 \mathrm{p}$.

BATES, J. D. 2005. Herbaceous response to cattle grazing following juniper cutting in Oregon. Range Ecology \& Management. 58:225-233.

Bates J., R. F. MilleR, AND T. S. SveJCAR. 1998. Understory patterns in cut western juniper (Juniperus occidentalis spp. occidentalis Hook.) woodlands. Great Basin Naturalist 58(4):363-374.

Bates J., R. F. Miller, and T. S. Svejcar. 1999. Plant succession in cut juniper woodlands: 1991-1998. In: Range Field Day 1999 Progress Report, juniper woodlands: history, ecology, and management, Special Report 1002, June 1999. Corvallis, OR: Agricultural Experiment Station, Oregon State University and USDA-Agricultural Research Service. p. 30-43

Bates J., R. F. Miller, and T. S. Svejcar. 2000. Understory dynamics in cut and uncut western juniper woodlands. Journal of Range Management 53:119-126.

Bates J., T. S. Svejcar, and R. F. Miller. 2002. Effects of juniper cutting on nitrogen mineralization. Journal of Arid Environments 51:221-234.

Bates J., T. Svejcar, and R. Miller. 2004. Forage production in a cut juniper woodland. In: T. Svejcar and J. Bates [EDS.]. Current forage and livestock production research, Special Report, June 2004. Agricultural Experiment Station, Oregon State University and USDA-Agricultural Research Service. p. 24-31.

BEDELL, T. E. 1987. Rehabilitation of western juniper rangeland: a case history. In: R.L. Everett [ED.]. Proceedings: Pinyon-Juniper Conference. Ogden, UT: Intermountain Research Station, USDA-For. Ser. Gen. Tech. Rep. INT-215. p. 313-315.

BeLsKY, A. J. 1996. Viewpoint: western juniper expansion: is it a threat to arid northwestern ecosystems? Journal of Range Management 49:53-59.

Blackburn, W. H., F. B. Pierson, G. E. Schuman, and R. E. Zartman [eds]. 1994. Variability of rangeland water erosion processes. Soil Science Society of America, Special Publication 38. Madison, Wisconsin: Soil Science Society of America, $106 \mathrm{p}$.

BuckHOUSE, J. C., AND J. L. MATTISON. 1980. Potential soil erosion of selected habitat types in the high desert region of central Oregon. Journal of Range Management 33:282-285.

CLARY, W. P. 1987. Herbage production and livestock grazing on pinyon-juniper woodlands. In: R. L. Everett [ED.]. Proceedings: Pinyon-Juniper Conference. Ogden, UT: Intermountain Research Station, USDA-For. Ser. Gen. Tech. Rep. INT-215. p. 440-447.

Davenport D. W., D. D. Breshears, B. P. Wilcox, and C. D. Allen. 1998. Viewpoint: 
sustainability of pinyon-juniper ecosystems-a unifying perspective of soil erosion thresholds. Journal of Range Management 51:231-240.

Davis, J. N., AND K. O. Harper. 1990. Weedy annuals and establishment of seeded species on a chained juniper-pinyon woodland in central Utah. In: E. D. McArthur [ED.]. Proceedings: Symposium on cheatgrass invasion, shrub dieoff and other aspects of shrub biology and management. Ogden, UT: USDAForest Service, Intermountain Research Station, Gen. Tech. Report INT-276. p. 79-82.

EddLeman, L. 1999. Ecological guidelines for management and restoration of pinyon and juniper woodlands. In: S. B. Monson and R. Stevens [Comps.]. Proceedings: Ecology and management of pinyon-juniper communities within the interior West. Ogden, UT: Rocky Mountain Research Station, USDA-For. Ser., Proceedings RMRS-P-9. p. 366-370.

EddLeman, L. 2002. Long term vegetation changes with and without juniper control. In: Range field day progress report, Department of Rangeland Resources, Oregon State University and Eastern Oregon Agricultural Research Center. Corvallis: Range Science Series Report \#5. p. 27-35.

Evans, R. A., And J. A. Young. 1985. Plant succession following control of western juniper (Juniperus occidentalis) with Picloram. Weed Science 33:63-68.

Ganskopp, D. C., And T. E. Bedell. 1979. Cheatgrass (Bromus tectorum) and its relationship to climate: a review. Corvallis, OR: Oregon Agricultural Experiment Station. Special Report 562, Oct 1979, 13 p.

Miller, R. F., J. D. Bates, T. J. Svejcar, F. B. Pierson, and L. E. Eddleman. 2005. Biology, ecology, and management of western juniper (Juniperus occidentalis). Corvallis: Oregon State University Agricultural Experiment Station Technical Bulletin 152. $77 \mathrm{p}$.

Miller, R. F., T. J. SvejCAR, and J. R. Rose. 2000. Impacts of western juniper on plant community composition and structure. Journal of Range Management 53:574-585.

Miller, R. F. and R. J. Tausch. 2001. The role of fire in juniper and pinyon woodlands: a descriptive analysis. In: K. E. M. Gailey and T. P. Wilson [EDs.]. Proceedings of the Invasive species workshop: the role of fire in the control and spread of invasive species. Tallahassee, FL: Tall Timbers Research Station, Misc. Publication No. 11. p. 15-30.

Miller, R. F., M. Willis, J. Rose, D. Reinkensmeyer, and B. Anthony. 1999. Effects of community structure on avian populations in juniper woodlands and shrub steppe. In: Range Field Day 1999 Progress Report, Department of Rangeland Resources, Oregon State University and Eastern Oregon Agricultural Research Center. Corvallis: Special Report 1002. p. 106-111.

NRCS. 2004. Oregon ecological site description, Loamy 12-16 PZ. Available at: http://esis.sc.egov.usda.gov/Welcome/fsReport.aspx?approved=yes\&id= R023XY3180R. United States Department of Agriculture, Natural Resources Conservation Service, Accessed March 4, 2004.

QuinseY, S. D. 1984. Fire and grazing effects in western juniper woodlands of central Oregon [thesis]. Seattle: University of Washington. $125 \mathrm{p}$.

Rose, J. R., and L. E. Eddleman. 1994. Ponderosa pine and understory growth following western juniper removal. Northwest Science 68:79-85.

SAS Institute. 2002. User's Guide, Release 8.03 Edition. Cary, NC: SAS Institute.

Skousen J. G., J. N. Davis, and J. D. Brotherson. 1989. Pinyon-juniper chaining and seeding for big game in central Utah. Journal of Range Management 42: 98-104.

Tausch, R. J., and P. T. Tueller. 1977. Plant succession following chaining of pinyon-juniper woodlands in eastern Nevada. Journal of Range Management 30:44-49.

VaitKus, M., AND L. E. EdDLEMAn. 1987. Composition and productivity of a western juniper understory and its response to canopy removal. In: R. L. Everett [ED.]. Proceedings: Pinyon-Juniper Conference. Ogden, UT: Intermountain Research Station, USDA-For. Ser. Gen. Tech. Rep. INT-215. p. 456-460.

Young, J. A., R. A. Evans, and C. Rimby. 1985. Weed control and revegetation following western juniper control. Weed Science 33:513-517. 